Sharif University of Technology
Scientia Iranica
SCIENTIA
I RAN I CA
Transactions A: Civil Engineering
www.scientiairanica.com

\title{
Data Envelopment Analysis (DEA) approach for making the bid/no-bid decision: A case study in a Turkish construction contracting company
}

\author{
G. Polat* and B.N. Bingol \\ Department of Civil Engineering, Istanbul Technical University, Maslak, 34469, Istanbul, Turkey. \\ Received 29 May 2015; received in revised form 26 November 2015; accepted 30 January 2016
}

\author{
KEYWORDS \\ Bidding decision; \\ $\mathrm{Bid} /$ no-bid decision; \\ Contracting \\ companies; \\ Construction projects; \\ Data envelopment \\ analysis; \\ Case study.
}

\begin{abstract}
Construction contracting companies face two critical decisions in competitive bidding environment, which include: the bid/no-bid decision and the mark-up selection decision. Making the right bid/no-bid decision is critical to the survival, sustainability, and success of the contractors in the industry. There are many factors that affect this decision. This makes the bidding decisions complex and complicated. Therefore, it is not an easy task for managers to consider the combined impact of all these factors on the bid/no-bid decision within a limited time frame with limited capacity of information they have for every single bidding opportunity. This study proposes a Data Envelopment Analysis (DEA) approach for making the bid/no-bid decision. DEA is a robust non-parametric linear programming approach, which is mostly used for benchmarking, performance measurement, and decision making problems. The applicability of the proposed approach was demonstrated in a real case study conducted in a Turkish construction contracting company. In the case study, 49 bidding opportunities formerly faced by the studied company were evaluated via the developed DEA model. The accuracy rate of the proposed approach was $92 \%$. Company management found the proposed approach satisfactory and implementable in future bid/nobid decision problems.

(C) 2017 Sharif University of Technology. All rights reserved.
\end{abstract}

\section{Introduction}

In general, construction projects are awarded to contractors via competitive bidding. When a new contract is announced, willing contractors mainly have to decide on: (i) Whether they will bid or not bid for the contract, and (ii) How much they will offer as the bid price, which consists of the base estimate (i.e., direct and indirect costs), and bid mark-up (i.e., general overhead cost, profit, and contingency) [1-3]. In a competitive business environment, contractors should prepare their bids wisely in order to be successful [1].

*. Corresponding author. Tel.: +90212 2853737 Email addresses: polatgu@itu.edu.tr (G. Polat); bbingol@itu.edu.tr (B.N.Bingol)
In this respect, deciding whether to bid for a job or not has a significant influence on the situation of the company in the future $[3,4]$. To decide not to bid for a project may bring about losing an opportunity to make a sizable profit, enhance strength and position in the industry, and develop a good relationship with a client $[3,5]$. On the other hand, bidding on all projects is not feasible and blindly bidding has several negative effects $[1,5]$. A construction company may decide to bid for a great number of contracts in order to increase the chances to win [3]. However, bidding is a very costly and time consuming process as it requires financial deposits for bidding documents, employees' hours, site visits, risk analysis, market analysis, etc. $[1,3,6]$. Indeed, recent studies revealed that the cost of preparing a bid estimate is approximately $0.25 \%-1 \%$ of the total 
bid price [7]. Since the construction companies have limited resources, they should plan wisely to make the maximum profit $[2,5]$. Moreover, in most cases, bidding for a contract does not mean the win. In the construction industry, the losses are more frequent than the wins [8]. If the losses are more frequent than the wins, the contractor's reputation in the market may be harmed $[1,3,9]$. Similarly, bidding for a project that does not comply with short and long-term strategies, capacity, and competency of the contractor may bring about a substantial waste of valuable time and resources, an adversarial relationship with the client, and possible arbitration or litigation [10], which in turn may result in interruption in the business continuity, growth, and success of the contractor [11].

Therefore, contractors should carefully eliminate losing proposals and thoroughly select the winning ones, which will assist them in achieving the short and long-term strategies, in order to stay in business, prevent waste of time and money, and enhance their reputation in the market [8].

It is commonly acknowledged that the bid/nobid decision is a complex and highly unstructured process that is affected by numerous interrelated factors concerning the contractor, the client, the contract and project characteristics, and the business environment (i.e., company's short and long-term strategies, competency, experience, resources, financial status, risk attitudes, management skills, the need of work, client profile, contract conditions, type of work, size of project, risk of project, economic conditions, competitors, available job opportunities, etc.) [3,9,12-17]. Therefore, it is not an easy task for a contractor to consider and assess the potential impacts of all these highly interrelated factors, in a limited amount of time with limited capacity of information, and to make a sound decision [4,18-19].

Over the years, the bid/no-bid decision has attracted the attention of numerous researchers and several methods have been developed to assist contractors in making bidding decisions. Most of these methods have primarily focused on optimizing the contractors' probability of winning contracts and determining the right bid mark-up size [4]. Undoubtedly, all these studies have considerably improved the bid/no-bid decision process. However, some of these models are too complex and impractical to be widely accepted, applied, and operated by construction professionals since they are based on complex computational and mathematical models and require much time to learn [20,21]. Indeed, $\mathrm{Li}$ and Love [22] argued that bidding decisions were simply made without much elaboration or deep reasoning. It is commonly acknowledged that contractors tend to make bidding decisions based on the intuition derived from a mixture of gut feeling, experience, and guesswork $[13,16,18,19,23-25]$. Egemen and
Mohamed [16] emphasized that developing a realistic model, which captured the complexity and uncertainty inherent in the bidding process, was very difficult. They also claimed that development of a systematic model would assist contractors in achieving business objectives, increasing productivity, and improving the quality of decision making.

The main objective of this study is to demonstrate how Data Envelopment Analysis (DEA) technique can be used as a decision support tool by construction contracting companies in their bid/no-bid decisions. DEA is a robust non-parametric linear programming approach, which is mostly used for benchmarking, performance measurement, and decision making problems. In this technique, several bidding factors, which can be either quantitative or qualitative, are simultaneously considered. One of the most important superiorities of DEA is that it can be easily employed by any construction company. In order to illustrate how DEA technique can be used for modeling the bid/no-bid decision in a construction company, a case study is also presented.

In addition to the studies most of which will be discussed in the next section, El-Mashaleh [9] and ElMashaleh [17] proposed DEA approach for the bid/nobid decision, which enables contractors to evaluate several bidding factors simultaneously and can be easily employed by any construction company. Although these studies made great contributions to the bid/nobid decision problem, they had some limitations. For instance, El-Mashaleh [9] deployed the DEA model on a hypothetical data set. On the other hand, ElMashaleh [17] proposed an empirical framework that was based on DEA. The suggested framework consisted of two major steps, which were identification of key factors that were considered by contractors when evaluating bid opportunities and utilization of DEA to make the bid/no-bid decision. In the first step of this study, 62 factors that might affect the bid/no-bid decision were identified based on the information gathered from the literature review; these factors were examined by a panel of four experts in the Jordanian construction industry who were top managers and had more than 27 years of experience; these 62 factors were modified to include 53 factors based on the panel's input; these 53 factors were categorized into 7 groups; a questionnaire was designed in order to identify the importance levels of these 53 factors; the questionnaire survey was administered to 43 Class I contractors operating in Jordan; the relative importance index of 53 factors was calculated and top 20 factors were included in the proposed DEA model. In the second step of this study, the proposed DEA model was practically illustrated based on the actual data of 39 bids obtained from 8 Jordanian contractors. Since these contractors were not able to supply 20 factors for their bids, 7 of them 
were excluded. Although this study is very valuable, it has some limitations. First, the factors included in the DEA model were selected based on the findings of a questionnaire survey conducted among 43 Jordanian contractors. However, the factors considered in the bid/no-bid decision greatly varied from company to company because of the differences in their strategies and capabilities. Therefore, every contractor had to identify the factors they considered during the bid/nobid decision. Second, the proposed framework was deployed based on the data collected from 8 Jordanian contractors. However, the bidding behavior also varied from company to company. Thus, every contractor had to develop his/her own DEA model based on the database, which contained the numerical assessment of the determined factors for all previously considered bids. Third, the bid/no-bid decision for new bidding opportunities was not made using the developed DEA model and the findings were not discussed. Fourth, validity and usability of the developed DEA model were not checked. This study aims to overcome the limitations of these two studies.

\section{Previous studies on bid/no-bid decision in the construction industry}

In the construction management literature, the bid/nobid decision problem has been studied by numerous researchers since the mid-1950s. These studies have different focuses. While a relatively large number of studies attempted to identify the most important factors affecting the contractors' bid/no-bid decision, few studies introduced bidding decision support systems based on various techniques.

Several studies have been conducted in different countries in order to identify the factors that have the largest influence on this decision. Ahmad and Minkarah [23] identified 31 factors and carried out a questionnaire survey in the USA. Shash [26] found that 55 potential factors influenced the bid/no-bid and mark-up decisions of top UK contractors and ranked top 5 factors as: need for work, number of competitors tendering, experience in such projects, current workload, and owner/promoter client identity. Wanous et al. [20] identified 38 factors, conducted a questionnaire survey among Syrian contractors, and concluded that fulfilling the tendering conditions, financial capability of the client, relation with/reputation of the client, project size, and availability of time for tendering were the most important factors. Chua and $\mathrm{Li}$ [14] identified 51 factors and categorized them into two main groups, which were: internal (i.e., capabilities and resources of the contractor) and external (i.e., characteristics of the project and environment). They carried out a survey of 153 top contractors in Singapore and developed a hierarchy, which contributed to 4 goals: competition, risk, need for work, and company's position in bidding process. Lowe and Parvar [27] identified 21 factors and categorized them into 7 main groups, which included: opportunities, resources, project relationships, project procedures, project characteristics, risks, and competitive advantage. They found that only 8 of these 21 factors had a linear relationship with the bid/nobid decision. Egemen and Mohamed [16] identified 83 factors and conducted a questionnaire survey among 80 small- to medium-sized contracting organizations from Northern Cyprus and Turkish construction markets. They discarded 33 of them as their importance levels were very low. The remaining 50 factors were classified into 3 main groups, which were: firm-related factors, project-related factors, and market conditions/demand \& strategic considerations. Bageis and Fortune [28] summarized 6 different studies and identified 87 factors. They carried out a survey of 91 contractors in Saudi Arabia and ranked top 5 factors as: the client's financial capacity, project cash flow, ability to do the project, availability of required cash, and work capital required to start the job. Enshassi et al. [12,29] investigated the factors affecting bid/no-bid decisions in the Palestinian and Gaza Strip construction industries. They found that financial capability of contractors, the reputation and financial capability of clients, financial values of projects, availability of raw materials in the local market, and the stability of the construction industry were the most important factors. Ravanshadnia et al. [6] developed a bid/no-bid decision hierarchy, which included: organizational considerations in bidding; project characteristics; risk; financial considerations; and project synergy, correlation, and portfolio effects. El-Mashaleh [17] identified 53 factors, categorized them into 7 groups (i.e., project characteristics, project bidding and contracting, project requirements, project expected benefits, client characteristics, consultant characteristics, firm and environmental factors), administered a questionnaire survey to 43 Class I contractors operating in Jordan, and ranked top 20 factors. Jarkas et al. [5] identified 43 factors and categorized them into 5 major groups, which were: employer-related, project-related, bidding situationrelated, contract-related, and contractor-related factors. They conducted a questionnaire survey among 92 Qatari contractors and found that previous experience with the employer, need for work, current workload, previous experience in similar projects, and size of project were the most important factors. Hwang and Kim [30] identified 22 factors and collected actual data of 182 cases from a specific Korean construction company. They found that completeness of drawing and specifications, size of the project, relationship with client's professional advisors, client reliability, clarity of bidding and contract procedure, and additional order scale were the most influential factors. Leśniak and 
Plebankiewicz [3] identified 16 factors, conducted a questionnaire survey among 61 Polish contractors, and ranked top 3 factors as: type of work, experience in similar projects, and contractual terms.

There are a number of studies that have introduced bidding decision support systems. The first attempt was by Ahmad [18]. He proposed a procedure based on a decision analysis technique, which assisted contractors in deciding whether to bid or not to bid for the contract under consideration. Wanous et al. [20] introduced a parametric bidding model, which was based on positive and negative bidding factors determined by contractors. Cagno et al. [31] described a simulation approach based on the analytic hierarchy process to assess the probability of winning in a competitive bidding process. Wanous et al. [32] described the development and testing of a bid/nobid model using the artificial neural network technique. Lin and Chen [15] proposed an assessment tool for contractors using fuzzy linguistic approach. Egemen and Mohamed [33] presented the development of practical knowledge-based system software, which systematically dealt with different bidding situations and assisted the contractors in reaching "strategically correct" bid/nobid decisions. Oo et al. [34] proposed a linear mixed model, which formulated bidding strategies according to project size, work sector, work nature, and number of bidders. Cheng et al. [24] proposed a multi-criteria prospect model for bidding decisions. Ravandshadnia et al. [6] developed a logical decision making framework, which covered organizational, environmental, risky, and financial considerations. Abbasianjahromi and Rajaie [2] presented a hybrid model according to the fuzzy case-based reasoning for prescreening of projects according to the factors generating risk in the construction industry and the historical records of the company, also allocating the most appropriate prescreened projects to the portfolio of company with the use of zero-one linear goal programming. Shafahi and Haghani [1] developed a customized genetic algorithm model, which took into account the importance of eminence and previous works. Polat et al. [35] proposed the use of adaptive neuro fuzzy inference method for modelling of the bid/no-bid decision. Leśniak and Plebankiewicz [3] developed a model, which incorporated fuzzy set theory. Hwang and Kim [30] proposed a model, which utilized logistic regression method.

\section{Data Envelopment Analysis (DEA)}

DEA, originally developed by Charnes et al. [3638 ], is a very powerful technique. It is extensively used in benchmarking, performance measurement, and decision making across different industries such as manufacturing, computing, banking, education, health care, etc. [17]. Several researchers [39-54] have suc- cessfully employed DEA in the construction industry for different purposes such as evaluation of contractors, selection of project location, evaluation of productivity and efficiency, assessment of credit scoring, purchase of construction materials, evaluation of design alternatives, benchmarking, assessment of performance, evaluation of contractors for bonding, etc. Despite the wide usage area of DEA in the construction industry, this technique has been utilized to make the bid/no-bid decision only in a limited number of studies (i.e. $[9,17]$ ). Therefore, DEA is selected as a decision support tool in this study.

Nonparametric linear programming is the underlying methodology of DEA, which makes it powerful when compared with other techniques [55]. DEA is based on an input-output framework, which aims to maximize the ratio of weighted outputs to the weighted inputs. In this method, inputs are minimized and outputs are maximized, and the relative efficiencies are evaluated via linear programming. There are 4 alternative models in DEA, which are CCR (CharnesCooper-Rhodes) ratio model, BCC (Banker-CharnesCooper) model, the multiplicative models, and the additive model [56]. The orientations of these models are categorized into 3 main groups, namely, inputoriented, output-oriented, and constant return scale. In input-oriented models, inputs are minimized while outputs are kept at their current values. On the other hand, in output-oriented models, outputs are maximized whereas inputs are kept at their current values.

In DEA, a Decision Making Unit (DMU) is used as an organizational unit $[9,17]$. The relative efficiency of DMU is measured based on the available data set for input and output variables [53]. In other words, DEA is a method to determine the efficiency by using linear programming, whose results evaluate the performances of DMUs.

The main idea behind DEA is to compare a certain number of DMUs carrying out similar tasks. Since the relative efficiency is measured without any assumptions, DEA is considered as nonparametric [17]. The strengths of DEA can be summarized as follows; (1) It is able to use large number of variables (inputs and outputs); (2) The input and output variables can be used in different measurement methods or units; and (3) There is no prior assumption, hence the weights of input and output variables are derived from the data [17].

An efficient frontier is a mathematical space, formed by the efficient DMUs, whose efficiency scores are equal to 1 . This frontier envelops all data points and it is determined by several computations of DEA. Efficiency score of each DMU is evaluated relative to an efficiency frontier. Efficiency score of each DMU ranges between 0 and 1 (i.e., $0 \leq$ efficiency score $\leq 1$ ). If DMU is located on the efficiency frontier, it has an efficiency score of 1 (or 100\%). If efficiency score of DMU 
is less than $1(<100 \%)$, then it is called inefficient DMU and its capacity needs to be improved for future performance. The efficient DMUs require fewer inputs to generate higher output [17]. Generally, inefficient DMUs use more inputs to produce lower output.

The mathematical form of DEA can be explained as follows; assume a set of $n$ DMUs $(j=1, \ldots, n)$ each consuming $m$ inputs $x_{i, j}(i=1, \ldots, m)$ to produce $s$ outputs $y_{r, j}(r=1, \ldots, s)$. The relative efficiency of a $\mathrm{DMU}_{j}$ can be computed with the following mathematical programming model (Eqs. (1)-(4)) by applying $n$ optimizations:

$$
\operatorname{Max} \theta_{j}=\frac{\sum_{r=1}^{s} u_{r} \times y_{r, j}}{\sum_{i=1}^{m} v_{i} \times x_{i, j}} .
$$

Subject to:

$$
\begin{aligned}
& \frac{\sum_{r=1}^{s} u_{r} \times y_{r, j}}{\sum_{i=1}^{m} v_{i} \times x_{i, j}} \leq 1 \quad j=1, \ldots, n, \\
& i=1, \ldots, m \quad r=1, \ldots, s, \\
& u_{r}, v_{i} \geq 0
\end{aligned}
$$

where $\theta_{j}$ is efficiency score of the $j$ th DMU, $r$ the number of output, $s$ the total number of outputs, $i$ the number of input, $m$ the total number of inputs, $j$ the number of DMU, $n$ the total number of DMUs, $u_{r}$ weight of the $r$ th output, $v_{i}$ weight of the $i$ th input, $y_{r, j}$ the $r$ th output of the $j$ th DMU, and $x_{i, j}$ the $i$ th input of the $j$ th DMU. The objective function of the mathematical programming relies on maximization of the efficiency of $\mathrm{DMU}_{j}$; and this is done by maximizing sum of numerator (outputs of $\mathrm{DMU}_{j}$ ) part divided by the sum of denominator (inputs of $\mathrm{DMU}_{j}$ ) part of the objective function (Eq. (1)). The efficiency scores of all DMUs have to be $\leq 1.0$ according to Eq. (2). Thus, all DMUs are located either on or below the efficient frontier [17].

\section{Proposed approach}

This study proposes an approach based on DEA, which can be easily employed by any construction contracting company for making the bid/no-bid decision. The proposed approach includes five main stages, which are: (1) Forming the decision making team and identifying the key factors that may affect the bid/no-bid decision in the construction contracting company in question; (2) Determining the inputs and outputs of the DEA model for the bid/no-bid decision; (3) Collecting data; (4) Performing DEA analysis on the collected data in order to measure the performance of the developed model; and (5) Making the bid/no-bid decision for new bidding opportunities.

\subsection{Forming the decision making team and identifying the key factors that may affect the bid/no-bid decision}

The decision making team, whose members are responsible for evaluating available job opportunities and making the bid/no-bid decisions in the construction contracting company in question, is formed. This team determines the factors that will be used by this company in the bid/no-bid decision. Since these factors greatly vary from company to company depending on the company's short- and long-term strategies; capacity; and bidding behavior, which is predominantly affected by market and economic conditions; number of competitors; type, size, location, and client of the project; contract conditions; contractor's financial status; opportunities and reputation that the project may provide; etc. [e.g. $[16,19,35])$, every construction company should determine these factors considering the prevailing conditions.

\subsection{Determining the inputs and outputs of the DEA model for the bid/no-bid decision}

The key factors that may affect the bid/no-bid decision, which are identified in the first stage, are categorized as inputs and outputs depending on whether they need to be minimized or maximized. The factors that need to be minimized should be categorized as inputs and the factors that need to be maximized should be categorized as outputs [9]. Then, the measurement methods of the factors are decided by the decision making team.

\subsection{Collecting data}

In this stage, the values of the variables (i.e., factors), which are categorized as inputs and outputs in the second stage, are determined for the previous bidding opportunities of the company in question. If the measurement method is determined to be subjective for any variable, the decision making team is requested to evaluate the variable(s) numerically on a pre-determined scale. If the measurement method is determined to be non-subjective for any variable, then the actual values of the variable(s) are used. After determining the values of the variables of the developed $\mathrm{bid} /$ no-bid decision model, a database is established.

\subsection{Performing DEA analysis on the collected data in order to measure the performance of the developed model}

DEA analysis is performed on the collected data and the efficiency scores for the bidding opportunities are calculated. In this stage, the actual decisions of the company in question and the decisions predicted by the developed DEA model on the previous bidding opportunities are compared, and the accuracy rate of the developed DEA model is calculated. If the calculated accuracy rate is satisfactory, then the developed model 
can be used for making the bid/no-bid decision for new bidding opportunities. If the calculated accuracy rate is not satisfactory, then the decision making team is requested to re-identify the key bidding factors until the accuracy rate becomes satisfactory.

\subsection{Making the bid/no-bid decision for new bidding opportunities}

In this stage, the decision makers determine the values of the inputs and outputs for new bidding opportunities and these values are added to the existing database. Then, the developed DEA model is re-run and the efficiency scores for the new bidding opportunities are calculated. If the efficiency score is found to be 1 for any of these opportunities, then the company may decide to bid. Otherwise, the company may decide not to bid.

\section{A numerical application of the proposed approach: A case study in a Turkish construction contracting company}

A case study is presented in order to illustrate how the proposed approach can be applied in a real situation. In this study, a large-scale Turkish construction constructing company, which predominantly undertakes international projects and is ranked among Top 225 International Contractors, is selected as a case study. The studied company is mainly specialized in marine works, infrastructure, industrial, and building projects, and undertakes projects in different countries such as, Azerbaijan, Bosnia and Herzegovina, Georgia, Libya, Qatar, and Turkey.

\subsection{Forming the decision making team and identifying the key factors that may affect the bid/no-bid decision in the studied company}

First, the decision making team was formed. This team consisted of three civil engineers, who were working in the contracting department of the studied company, had at least 20 years of experience in the construction industry, and were in charge of evaluating available job opportunities and making the bid/no-bid decisions. In order to identify the key factors that might affect the bid/no-bid decision in this company, these professionals were interviewed. Based on these interviews, 16 key factors were taken into account during the bid/nobid decision process in the studied company, which included: (1) Complexity of bidding documents (i.e., drawings, specifications); (2) Unfamiliarity with the specific type of work; (3) Cash flow requirements of the project; (4) Technological difficulty of the project; (5) Unsatisfactory terms of payment; (6) Percentage of retention money; (7) Project's contribution to the strength of company brand and reputation; (8) Project's contribution to the increase in the interna- tional market share of the company; (9) Project's contribution to the development of long-term relationships with other companies; (10) Project's contribution to the improvement of the employees; (11) Potential for gaining similar projects in the future; (12) Potential for gaining long-term profit; (13) Contract price; (14) Project duration; (15) Percentage of advance payment; and (16) Tender preparation time.

\subsection{Determining the inputs and outputs of the DEA model for the bid/no-bid decision in the studied company}

After identifying the key factors that might affect the bid/no-bid decision in the studied company, these factors were categorized as inputs or outputs. The factors that needed to be minimized were categorized as inputs and the factors that needed to be maximized were categorized as outputs [9]. In the proposed DEA model, the first 6 factors (i.e., $\mathrm{NF}_{1}-\mathrm{NF}_{6}$ ), namely, $\left(\mathrm{NF}_{1}\right)$ complexity of bidding documents (i.e., drawings, specifications), $\left(\mathrm{NF}_{2}\right)$ unfamiliarity with this specific type of work, $\left(\mathrm{NF}_{3}\right)$ cash flow requirements of the project, $\left(\mathrm{NF}_{4}\right)$ technological difficulty of the project, $\left(\mathrm{NF}_{5}\right)$ unsatisfactory terms of payment, $\left(\mathrm{NF}_{6}\right)$ percentage of retention money, which had negative effects on the bid decision, were quantified as inputs. The remaining 10 factors $\left(\mathrm{PF}_{1}-\mathrm{PF}_{10}\right)$, namely $\left(\mathrm{PF}_{1}\right)$ project's contribution to the strength of company brand and reputation, $\left(\mathrm{PF}_{2}\right)$ project's contribution to the increase in the international market share of the company, $\left(\mathrm{PF}_{3}\right)$ project's contribution to the development of long-term relationships with other companies, $\left(\mathrm{PF}_{4}\right)$ project's contribution to the improvement of the employees, $\left(\mathrm{PF}_{5}\right)$ potential for gaining similar projects in the future, $\left(\mathrm{PF}_{6}\right)$ potential for gaining long-term profit, $\left(\mathrm{PF}_{7}\right)$ contract price, $\left(\mathrm{PF}_{8}\right)$ project duration, $\left(\mathrm{PF}_{9}\right)$ percentage of advance payment, $\left(\mathrm{PF}_{10}\right)$ tender preparation time, were quantified as outputs as they had positive effects on the bid decision and needed to be maximized.

The variables' abbreviations, definitions, and their measurement methods are presented in Table 1.

As seen in Table 1, the measurement method of the variables, i.e. percentage of retention money $\left(\mathrm{NF}_{6}\right)$, contract price $\left(\mathrm{PF}_{7}\right)$, project duration $\left(\mathrm{PF}_{8}\right)$, percentage of advance payment $\left(\mathrm{PF}_{9}\right)$, and tender preparation time $\left(\mathrm{PF}_{10}\right)$, is numerical and the actual values of these variables are used as inputs or outputs. On the other hand, the measurement method of the remaining variables is not numerical. The decision makers individually and subjectively evaluate these variables on a 1-5 scale, where 1 denotes "Very Low" and 5 denotes "Very High".

\subsection{Collecting data in the studied company}

After determining the inputs and outputs of the pro- 
Table 1. Variables of the proposed DEA model.

\begin{tabular}{|c|c|c|c|}
\hline $\begin{array}{c}\text { Variable } \\
\text { abbreviation }\end{array}$ & Variable definition & $\begin{array}{c}\text { Measurement } \\
\text { method }\end{array}$ & Input/output \\
\hline $\mathrm{NF}_{1}$ & $\begin{array}{l}\text { Complexity of bidding documents } \\
\text { (i.e., drawings, specifications) }\end{array}$ & Subjective score & Input \\
\hline $\mathrm{NF}_{2}$ & Unfamiliarity with this specific type of work & Subjective score & Input \\
\hline $\mathrm{NF}_{3}$ & Cash flow requirements of the project & Subjective score & Input \\
\hline $\mathrm{NF}_{4}$ & Technological difficulty of the project & Subjective score & Input \\
\hline $\mathrm{NF}_{5}$ & Unsatisfactory terms of payment & Subjective score & Input \\
\hline $\mathrm{NF}_{6}$ & Percentage of retention money & $\%$ & Input \\
\hline $\mathrm{PF}_{1}$ & $\begin{array}{l}\text { Project's contribution to the strength of } \\
\text { company brand and reputation }\end{array}$ & Subjective score & Output \\
\hline $\mathrm{PF}_{2}$ & $\begin{array}{l}\text { Project's contribution to the increase } \\
\text { in the international market share of the company }\end{array}$ & Subjective score & Output \\
\hline $\mathrm{PF}_{3}$ & $\begin{array}{l}\text { Project's contribution to the development of } \\
\text { long-term relationships with other companies }\end{array}$ & Subjective score & Output \\
\hline $\mathrm{PF}_{4}$ & $\begin{array}{l}\text { Project's contribution to the } \\
\text { improvement of the employees }\end{array}$ & Subjective score & Output \\
\hline $\mathrm{PF}_{5}$ & Potential for gaining similar projects in the future & Subjective score & Output \\
\hline $\mathrm{PF}_{6}$ & Potential for gaining long-term profit & Subjective score & Output \\
\hline $\mathrm{PF}_{7}$ & Contract price & $\$(\times 1,000,000)$ & Output \\
\hline $\mathrm{PF}_{8}$ & Project duration & \# of months & Output \\
\hline $\mathrm{PF}_{9}$ & Percentage of advance payment & $\%$ & Output \\
\hline $\mathrm{PF}_{10}$ & Tender preparation time & \# of days & Output \\
\hline
\end{tabular}

posed bid/no-bid decision model and their measurement methods, the actual values of these variables were determined. For this purpose, the studied contracting company's database was used. The database included: (1) each decision maker's (i.e., three civil engineers working in the contracting department of the studied company) numerical evaluations of the inputs $\mathrm{NF}_{1}$, $\mathrm{NF}_{2}, \mathrm{NF}_{3}, \mathrm{NF}_{4}$, and $\mathrm{NF}_{5}$, and the outputs $\mathrm{PF}_{1}, \mathrm{PF}_{2}$, $\mathrm{PF}_{3}, \mathrm{PF}_{4}, \mathrm{PF}_{5}$, and $\mathrm{PF}_{6}$ on a 1-5 subjective scale, where 1 denotes "Very Low" and 5 denotes "Very High", and (2) actual values of the input $\mathrm{NF}_{6}$ and the outputs $\mathrm{PF}_{7}, \mathrm{PF}_{8}, \mathrm{PF}_{9}, \mathrm{PF}_{10}$ for 49 bidding opportunities (i.e., BO01-BO49) previously considered in the last three years. In the DEA model, each bidding opportunity is considered as DMU. The decision makers decided to bid for 30 of them and not to bid for 19 of them. The arithmetic means of the decision makers' numerical evaluations and actual values of the inputs and outputs for 49 bidding opportunities are presented in Table 2.

In Table 2, BO01-BO49 refers to bidding opportunities that had been previously considered by the studied contracting company in the last three years. For instance, BO01 was a housing project in Azerbaijan, whose percentage of retention money was $5 \%\left(\mathrm{NF}_{6}\right)$, contract price was $\$ 35,000,000\left(\mathrm{PF}_{7}\right)$, project duration was 18 months $\left(\mathrm{PF}_{8}\right)$, percentage of advance payment was $10 \%\left(\mathrm{PF}_{9}\right)$, and tender preparation time was 40 days $\left(\mathrm{PF}_{10}\right)$. The actual values of these variables are used. On the other hand, the values of the remaining variables (i.e., $\mathrm{NF}_{1}, \mathrm{NF}_{2}, \mathrm{NF}_{3}, \mathrm{NF}_{4}, \mathrm{NF}_{5}, \mathrm{PF}_{1}, \mathrm{PF}_{2}$, $\left.\mathrm{PF}_{3}, \mathrm{PF}_{4}, \mathrm{PF}_{5}, \mathrm{PF}_{6}\right)$ are considered as the arithmetic means of three decision makers' numerical evaluations on a 1-5 subjective scale, where 1 denotes "Very Low" and 5 denotes "Very High".

It should be kept in mind that large numbers of inputs and outputs and small number of DMUs (i.e., bidding opportunities) may weaken the discriminatory power of DEA. Although different researchers have suggested different rules for determining the appropriate number of DMUs depending on the numbers of inputs and outputs, there is no general consensus. For instance, while Golany and Roll [57] stated that the number of DMUs should be at least twice the sum of the numbers of the inputs and outputs, Banker et al. [58] suggested that the number of DMUs should be at least three times the sum of the numbers of the inputs and outputs. In this study, since the number of DMUs (i.e., the number of bidding opportunities) is 49 
Table 2. Numerical evaluations and actual values of the inputs and outputs for 49 bidding opportunities.

\begin{tabular}{|c|c|c|c|c|c|c|c|c|c|c|c|c|c|c|c|c|}
\hline $\begin{array}{c}\text { Bid. Opp. } \\
\#\end{array}$ & $\mathrm{NF}_{1}$ & $\mathrm{NF}_{2}$ & $\mathrm{NF}_{3}$ & $\mathrm{NF}_{4}$ & $\mathrm{NF}_{5}$ & $\mathrm{NF}_{6}$ & $\mathrm{PF}_{1}$ & $\mathrm{PF}_{2}$ & $\mathrm{PF}_{3}$ & $\mathrm{PF}_{4}$ & $\mathrm{PF}_{5}$ & $\mathrm{PF}_{6}$ & $\mathrm{PF}_{7}$ & $\mathrm{PF}_{8}$ & $\mathrm{PF}_{9}$ & $\mathrm{PF}_{10}$ \\
\hline BO01 & 2.33 & 1.00 & 2.33 & 1.00 & 1.00 & 5 & 3.00 & 3.33 & 2.67 & 2.67 & 3.67 & 2.67 & 35 & 18 & 10 & 40 \\
\hline BO02 & 2.33 & 2.33 & 1.33 & 1.00 & 2.67 & 5 & 2.67 & 3.33 & 3.33 & 3.67 & 4.00 & 4.00 & 21 & 31 & 5 & 20 \\
\hline BO03 & 1.00 & 1.67 & 1.33 & 1.00 & 1.00 & 2 & 4.00 & 3.00 & 2.33 & 5.33 & 4.33 & 4.33 & 60 & 33 & 20 & 30 \\
\hline BO04 & 1.67 & 1.33 & 1.67 & 1.33 & 1.00 & 5 & 2.67 & 1.33 & 1.33 & 1.67 & 1.67 & 1.67 & 70 & 10 & 15 & 25 \\
\hline BO05 & 1.67 & 1.67 & 3.33 & 1.33 & 1.67 & 2 & 3.33 & 3.33 & 2.67 & 4.67 & 5.67 & 3.33 & 28 & 28 & 5 & 30 \\
\hline BO06 & 1.33 & 1.33 & 1.67 & 1.33 & 1.67 & 4 & 4.00 & 4.00 & 4.33 & 5.67 & 4.00 & 4.33 & 64 & 28 & 15 & 28 \\
\hline BO07 & 1.00 & 1.33 & 1.33 & 1.00 & 1.33 & 1 & 2.67 & 3.67 & 1.67 & 2.67 & 3.00 & 3.00 & 40 & 20 & 11 & 20 \\
\hline BO08 & 1.67 & 1.00 & 1.67 & 1.67 & 1.33 & 2 & 4.00 & 2.67 & 3.00 & 4.67 & 2.67 & 4.00 & 50 & 22 & 16 & 30 \\
\hline BO09 & 2.00 & 1.67 & 1.33 & 1.00 & 1.00 & 2 & 4.00 & 4.33 & 4.00 & 3.67 & 4.00 & 4.33 & 14 & 24 & 5 & 24 \\
\hline BO10 & 1.33 & 1.33 & 3.00 & 1.00 & 1.67 & 2 & 3.33 & 3.67 & 3.67 & 4.33 & 5.33 & 3.33 & 12 & 16 & 5 & 32 \\
\hline BO11 & 1.67 & 1.33 & 1.33 & 1.67 & 1.33 & 2 & 4.00 & 4.67 & 5.67 & 3.67 & 5.00 & 3.33 & 38 & 22 & 5 & 25 \\
\hline BO12 & 1.33 & 2.00 & 3.67 & 1.33 & 1.00 & 5 & 4.33 & 3.00 & 2.33 & 2.67 & 3.67 & 4.33 & 55 & 36 & 10 & 30 \\
\hline BO13 & 1.67 & 1.33 & 1.00 & 1.67 & 1.00 & 2 & 4.00 & 3.00 & 4.00 & 2.67 & 3.67 & 3.00 & 60 & 18 & 15 & 35 \\
\hline BO14 & 3.00 & 1.33 & 1.00 & 2.33 & 1.33 & 5 & 5.00 & 4.33 & 5.00 & 5.00 & 5.33 & 4.67 & 165 & 96 & 20 & 40 \\
\hline BO15 & 1.67 & 3.00 & 2.67 & 1.33 & 1.00 & 2 & 2.33 & 1.67 & 1.67 & 2.33 & 3.33 & 3.33 & 20 & 18 & 15 & 35 \\
\hline BO16 & 1.33 & 1.33 & 2.33 & 1.33 & 1.33 & 5 & 3.67 & 3.33 & 4.00 & 5.00 & 5.33 & 5.00 & 105 & 36 & 20 & 30 \\
\hline BO17 & 2.33 & 2.33 & 1.00 & 1.33 & 1.00 & 5 & 3.33 & 4.33 & 3.67 & 5.00 & 4.67 & 4.00 & 67 & 24 & 20 & 35 \\
\hline BO18 & 2.33 & 3.00 & 3.00 & 1.67 & 1.33 & 1 & 5.67 & 3.67 & 3.00 & 3.00 & 4.33 & 3.67 & 81 & 28 & 10 & 30 \\
\hline BO19 & 1.00 & 1.33 & 1.33 & 1.00 & 1.33 & 2 & 4.33 & 4.33 & 4.33 & 2.33 & 5.00 & 4.00 & 20 & 18 & 10 & 24 \\
\hline BO20 & 1.33 & 1.67 & 1.67 & 2.00 & 2.33 & 5 & 4.00 & 2.67 & 3.00 & 4.67 & 4.33 & 3.00 & 28 & 14 & 15 & 25 \\
\hline BO21 & 2.67 & 1.33 & 1.00 & 1.33 & 1.00 & 2 & 4.00 & 3.33 & 4.67 & 4.33 & 3.00 & 4.00 & 36 & 24 & 20 & 35 \\
\hline BO22 & 1.33 & 2.33 & 3.67 & 3.00 & 1.67 & 5 & 3.67 & 2.67 & 4.00 & 5.33 & 3.67 & 2.33 & 15 & 20 & 20 & 40 \\
\hline BO23 & 1.67 & 1.33 & 1.33 & 1.00 & 1.33 & 2 & 2.33 & 2.00 & 2.33 & 4.33 & 4.33 & 1.33 & 55 & 9 & 10 & 20 \\
\hline BO24 & 1.67 & 1.67 & 2.00 & 1.33 & 1.33 & 5 & 4.67 & 4.67 & 4.67 & 4.67 & 5.33 & 5.00 & 102 & 24 & 10 & 20 \\
\hline BO25 & 1.33 & 1.00 & 1.00 & 1.33 & 1.67 & 2 & 4.33 & 2.33 & 2.33 & 3.33 & 3.00 & 2.67 & 70 & 24 & 15 & 25 \\
\hline BO26 & 1.00 & 2.00 & 3.67 & 1.33 & 1.67 & 2 & 4.67 & 3.67 & 3.33 & 5.00 & 5.00 & 5.67 & 190 & 36 & 10 & 30 \\
\hline BO27 & 1.33 & 2.67 & 1.00 & 1.00 & 1.67 & 4 & 3.33 & 2.33 & 3.33 & 4.33 & 3.00 & 4.00 & 150 & 36 & 5 & 30 \\
\hline BO28 & 1.67 & 1.33 & 1.67 & 1.33 & 1.00 & 5 & 4.33 & 4.00 & 4.33 & 3.67 & 3.67 & 4.00 & 195 & 30 & 10 & 35 \\
\hline BO29 & 1.33 & 1.33 & 3.00 & 1.33 & 1.67 & 4 & 5.67 & 5.33 & 4.67 & 4.67 & 5.33 & 3.33 & 25 & 24 & 5 & 25 \\
\hline BO30 & 1.00 & 1.67 & 1.67 & 1.67 & 1.00 & 4 & 5.33 & 3.67 & 4.00 & 5.00 & 5.00 & 2.33 & 87 & 23 & 5 & 20 \\
\hline BO31 & 3.33 & 3.00 & 2.33 & 1.67 & 1.33 & 5 & 3.67 & 2.67 & 2.33 & 3.00 & 3.67 & 3.33 & 10 & 24 & 10 & 20 \\
\hline BO32 & 1.67 & 3.00 & 2.33 & 3.33 & 3.33 & 5 & 3.33 & 2.33 & 1.67 & 3.00 & 1.67 & 1.67 & 52 & 18 & 15 & 15 \\
\hline BO33 & 2.67 & 3.33 & 3.00 & 4.33 & 1.67 & 5 & 3.67 & 1.67 & 3.67 & 3.33 & 3.00 & 2.67 & 65 & 20 & 20 & 25 \\
\hline BO34 & 3.67 & 3.67 & 3.67 & 1.67 & 3.00 & 2 & 2.67 & 2.67 & 1.67 & 2.00 & 2.00 & 2.33 & 34 & 10 & 10 & 20 \\
\hline BO35 & 2.00 & 2.67 & 2.33 & 2.67 & 3.67 & 2 & 2.67 & 1.67 & 2.33 & 3.00 & 2.33 & 2.33 & 44 & 12 & 10 & 15 \\
\hline BO36 & 5.33 & 1.33 & 3.67 & 1.67 & 2.67 & 5 & 3.67 & 2.67 & 3.00 & 2.67 & 3.00 & 3.67 & 200 & 32 & 10 & 25 \\
\hline BO37 & 4.33 & 2.33 & 3.00 & 1.00 & 3.00 & 5 & 4.00 & 2.67 & 1.67 & 4.00 & 3.67 & 1.67 & 15 & 12 & 10 & 20 \\
\hline BO38 & 2.33 & 2.67 & 2.67 & 2.67 & 1.33 & 5 & 3.67 & 3.33 & 2.67 & 2.33 & 3.67 & 3.33 & 21 & 18 & 10 & 15 \\
\hline BO39 & 4.00 & 2.33 & 4.00 & 1.33 & 2.33 & 2 & 2.33 & 2.33 & 1.67 & 3.00 & 3.00 & 1.33 & 15 & 9 & 15 & 10 \\
\hline BO40 & 1.67 & 1.67 & 1.33 & 1.00 & 1.00 & 2 & 4.00 & 4.67 & 4.00 & 3.67 & 4.33 & 4.33 & 87.5 & 24 & 10 & 25 \\
\hline BO41 & 4.67 & 3.00 & 4.33 & 3.67 & 2.33 & 2 & 2.67 & 3.00 & 2.33 & 1.67 & 2.33 & 1.00 & 25 & 12 & 15 & 25 \\
\hline BO42 & 4.33 & 1.67 & 3.00 & 1.67 & 1.67 & 5 & 3.00 & 3.67 & 1.67 & 2.67 & 2.67 & 3.67 & 35 & 16 & 10 & 10 \\
\hline BO43 & 5.00 & 4.00 & 3.00 & 3.00 & 2.67 & 5 & 2.67 & 3.67 & 3.00 & 3.33 & 4.33 & 1.67 & 86 & 18 & 10 & 25 \\
\hline BO44 & 4.33 & 4.00 & 2.67 & 2.33 & 3.33 & 5 & 3.00 & 2.33 & 2.33 & 4.33 & 3.00 & 2.00 & 52 & 14 & 15 & 15 \\
\hline BO45 & 4.67 & 4.67 & 4.33 & 2.33 & 3.00 & 5 & 4.67 & 3.33 & 2.67 & 2.67 & 3.00 & 3.33 & 35 & 16 & 10 & 15 \\
\hline BO46 & 4.33 & 4.33 & 3.33 & 3.00 & 1.67 & 5 & 4.67 & 4.33 & 3.67 & 3.67 & 2.67 & 4.33 & 250 & 36 & 10 & 15 \\
\hline BO47 & 3.00 & 4.00 & 3.33 & 3.00 & 1.33 & 5 & 4.33 & 3.33 & 4.00 & 4.33 & 4.00 & 3.00 & 75 & 20 & 15 & 25 \\
\hline BO48 & 3.00 & 4.00 & 2.33 & 3.33 & 3.67 & 5 & 3.33 & 2.33 & 4.00 & 4.33 & 4.67 & 2.67 & 180 & 28 & 10 & 25 \\
\hline BO49 & 3.33 & 1.67 & 3.33 & 1.67 & 1.67 & 5 & 3.33 & 2.67 & 3.33 & 3.67 & 4.67 & 3.33 & 150 & 24 & 10 & 20 \\
\hline
\end{tabular}


and the sum of the numbers of the inputs and outputs is 16 , the suggested rules are satisfied.

\subsection{Performing DEA analysis on the collected data in order to measure the performance of the developed model in the studied company}

The framework of the proposed bid/no-bid decision model is shown in Figure 1. As seen in Figure 1, the database includes the values of the inputs (i.e., $\mathrm{NF}_{1-6}$ ) and outputs (i.e., $\mathrm{PF}_{1-10}$ ) for each bidding opportunity (i.e., DMU). DEA analysis is conducted on 49 DMUs and the efficiency scores are calculated. If the efficiency score is equal to 1 , this means that this bidding opportunity belongs to the efficient frontier and the decision for this bidding opportunity should be "bid". Otherwise, the decision should be "no bid".

Having collected the data presented in Table 2 from the studied company's database, the proposed DEA model was run via OSDEA software. In order to calculate the efficiency scores of 49 bidding opportunities, the following equations (Eqs. (5)-(8)) were used:

$$
\operatorname{Max} \theta_{j}=\frac{\sum_{r=1}^{s} u_{r} \times \mathrm{PF}_{r, j}}{\sum_{i=1}^{m} v_{i} \times \mathrm{NF}_{i, j}} .
$$

Subject to :

$$
\begin{aligned}
& \frac{\sum_{r=1}^{s} u_{r} \times \mathrm{PF}_{r, j}}{\sum_{i=1}^{m} v_{i} \times \mathrm{NF}_{i, j}} \leq 1, \quad j=1, \ldots, n, \\
& i=1, \ldots, m, \quad r=1, \ldots, s \\
& u_{r}, v_{i} \geq 0
\end{aligned}
$$

where $\theta_{j}$ is efficiency score of the $j$ th DMU (i.e., bidding opportunity), $r$ the number of output (i.e., $\mathrm{PF}$ ), $s$ the total number of outputs (i.e., 10), $i$ the number of input (i.e., NF), $m$ the total number of inputs (i.e., 6), $j$ the number of DMU, $n$ the total number of DMUs (i.e., 49), $u_{r}$ weight of the $r$ th output, $v_{i}$ weight of the $i$ th input, $\mathrm{PF}_{r, j}$ the $r$ th $\mathrm{PF}$ of the $j$ th DMU, and $\mathrm{NF}_{i, j}$ the $i$ th $\mathrm{NF}$ of the $j$ th DMU.

The efficiency scores calculated according to Eqs. (5)-(8), actual decisions of the studied company, and the decisions predicted by the developed DEA model for 49 bidding opportunities are displayed in Table 3.

As seen in Table 3, the efficient frontier of the developed model includes 30 bidding opportunities, which are BO01, BO02, BO03, BO05, BO06, BO07, $\mathrm{BO} 08$, BO09, BO10, BO11, BO12, BO13, BO14, $\mathrm{BO} 15, \mathrm{BO} 16, \mathrm{BO} 17, \mathrm{BO} 18, \mathrm{BO} 19, \mathrm{BO} 21, \mathrm{BO} 22$, $\mathrm{BO} 23, \mathrm{BO} 24$, BO25, BO26, BO27, BO28, BO29, $\mathrm{BO} 30, \mathrm{BO} 36$, and $\mathrm{BO} 40$ as their efficiency scores are equal to 1.00 . On the other hand, the efficiency scores for the remaining 19 bidding opportunities are found to be lower than 1.00 , which indicates that these bidding opportunities do not belong to the efficient frontier and the studied company should have not bidden for these opportunities. In real life, the studied contracting company made a positive bidding decision for the bidding opportunities on the efficient frontier, except BO36 and BO40. The studied company made a positive bidding decision for the bidding opportunities BO04 and BO20, although they were not a part of the efficient frontier. It can be concluded that the actual decisions of the decision makers and the decisions predicted by the developed DEA model are consistent for 45 bidding opportunities out of 49 bidding opportunities, which corresponds to an accuracy rate of $92 \%$. When the decision makers were asked to evaluate the findings of the developed DEA model, they stated that they had made wrong decisions for these 4 bidding opportunities and the results of the developed DEA model were very reasonable.

\subsection{Making the bid/no-bid decision for new bidding opportunities in the studied company}

The studied construction contracting company had two new bidding opportunities (i.e., BO50 and BO51).

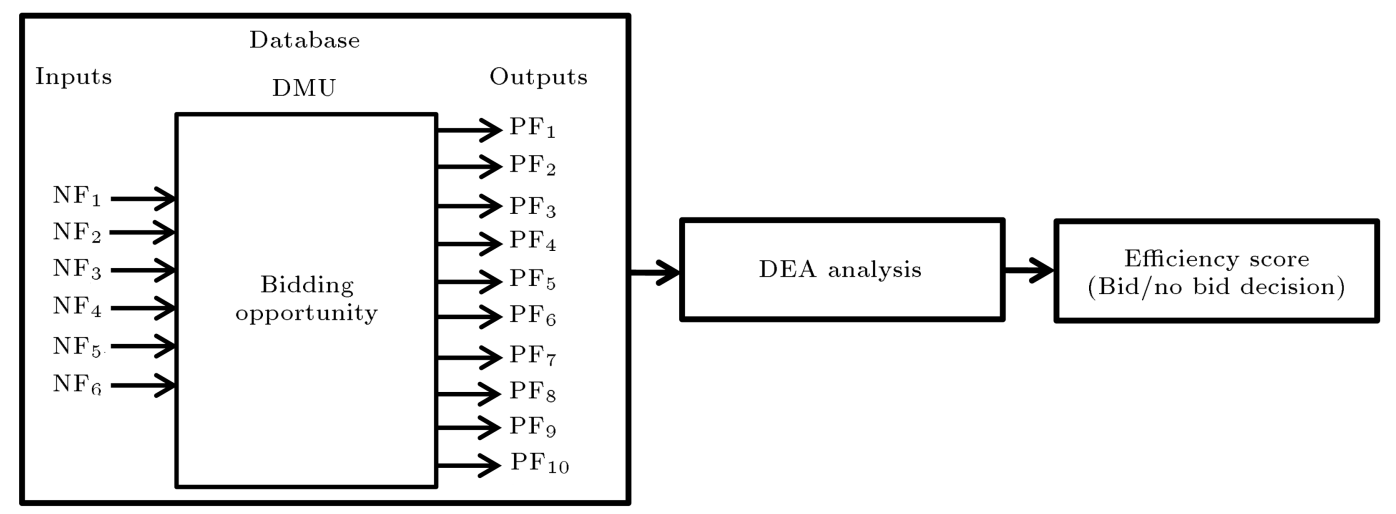

Figure 1. Framework of the proposed bid/no-bid decision model. 
Table 3. Efficiency scores for the bidding opportunities.

\begin{tabular}{|c|c|c|c|c|c|c|c|c|c|c|c|}
\hline $\begin{array}{c}\text { Bid. } \\
\text { Opp. \# }\end{array}$ & $\begin{array}{l}\text { Eff. } \\
\text { Sco. }\end{array}$ & $\begin{array}{l}\text { Act. } \\
\text { Dec. }\end{array}$ & $\begin{array}{c}\text { Pred. } \\
\text { Dec. }\end{array}$ & $\begin{array}{c}\text { Bid. } \\
\text { Opp. \# }\end{array}$ & $\begin{array}{l}\text { Eff. } \\
\text { Sco. }\end{array}$ & $\begin{array}{l}\text { Act. } \\
\text { Dec. }\end{array}$ & $\begin{array}{c}\text { Pred. } \\
\text { Dec. }\end{array}$ & $\begin{array}{c}\text { Bid. } \\
\text { Opp. \# }\end{array}$ & $\begin{array}{l}\text { Eff. } \\
\text { Sco. }\end{array}$ & $\begin{array}{l}\text { Act. } \\
\text { Dec. }\end{array}$ & $\begin{array}{c}\text { Pred. } \\
\text { Dec. }\end{array}$ \\
\hline BO01 & 1.00 & Bid & Bid & BO18 & 1.00 & Bid & Bid & BO35 & 0.59 & No bid & No bid \\
\hline BO02 & 1.00 & Bid & Bid & BO19 & 1.00 & Bid & Bid & BO36 & 1.00 & No bid & Bid \\
\hline BO03 & 1.00 & Bid & Bid & BO20 & 0.86 & Bid & No bid & BO37 & 0.96 & No Bid & No bid \\
\hline BO04 & 0.84 & Bid & No bid & BO21 & 1.00 & Bid & Bid & BO38 & 0.64 & No bid & No bid \\
\hline BO05 & 1.00 & Bid & Bid & $\mathrm{BO} 22$ & 1.00 & Bid & Bid & BO39 & 0.73 & No bid & No bid \\
\hline BO06 & 1.00 & Bid & Bid & $\mathrm{BO} 23$ & 1.00 & Bid & Bid & BO40 & 1.00 & No bid & Bid \\
\hline BO07 & 1.00 & Bid & Bid & $\mathrm{BO} 24$ & 1.00 & Bid & Bid & BO41 & 0.69 & No bid & No bid \\
\hline BO08 & 1.00 & Bid & Bid & $\mathrm{BO} 25$ & 1.00 & Bid & Bid & BO42 & 0.69 & No bid & No bid \\
\hline BO09 & 1.00 & Bid & Bid & $\mathrm{BO} 26$ & 1.00 & Bid & Bid & BO43 & 0.43 & No bid & No bid \\
\hline BO10 & 1.00 & Bid & Bid & $\mathrm{BO} 27$ & 1.00 & Bid & Bid & BO44 & 0.39 & No bid & No bid \\
\hline BO11 & 1.00 & Bid & Bid & BO28 & 1.00 & Bid & Bid & BO45 & 0.47 & No bid & No bid \\
\hline BO12 & 1.00 & Bid & Bid & BO29 & 1.00 & Bid & Bid & BO46 & 0.98 & No bid & No bid \\
\hline BO13 & 1.00 & Bid & Bid & BO30 & 1.00 & Bid & Bid & BO47 & 0.75 & No bid & No bid \\
\hline BO14 & 1.00 & Bid & Bid & BO31 & 0.64 & No bid & No bid & BO48 & 0.81 & No bid & No bid \\
\hline BO15 & 1.00 & Bid & Bid & BO32 & 0.48 & No bid & No bid & BO49 & 0.85 & No bid & No bid \\
\hline BO16 & 1.00 & Bid & Bid & BO33 & 0.65 & No bid & No bid & & & & \\
\hline BO17 & 1.00 & Bid & Bid & BO34 & 0.53 & No bid & No bid & & & & \\
\hline
\end{tabular}

Note: Bid. Opp. stands for bidding opportunity, Eff. Sco. stands for efficiency score, Act. Dec. stands for actual decision,

Pred. Dec. stands for predicted decision, BO stands for bidding opportunity, NF stands for negative bidding factors,

and PF stands for positive bidding factors.

BO50 was a port project in Oman and BO51 was a housing project in Azerbaijan. The decision makers desired to decide whether they would bid for these opportunities or not using the developed DEA model. For this purpose, the decision makers individually evaluated the inputs $\mathrm{NF}_{1}, \mathrm{NF}_{2}, \mathrm{NF}_{3}, \mathrm{NF}_{4}, \mathrm{NF}_{5}$ and outputs $\mathrm{PF}_{1}, \mathrm{PF}_{2}, \mathrm{PF}_{3}, \mathrm{PF}_{4}, \mathrm{PF}_{5}, \mathrm{PF}_{6}$ on a 1-5 subjective scale, where 1 denoted "Very Low" and 5 denoted "Very High", for these new bidding opportunities. Then, the arithmetic means of their evaluations were calculated. These arithmetic means and the actual values of the remaining input $\mathrm{NF}_{6}$ and outputs $\mathrm{PF}_{7}, \mathrm{PF}_{8}, \mathrm{PF}_{9}$, and $\mathrm{PF}_{10}$ were added as the inputs' and outputs' numerical values to the database, which had already included the data of 49 bidding opportunities. The numerical values of the inputs and outputs for 2 new bidding opportunities are presented in Table 4.

Having identified the values of the inputs and outputs of BO50 and BO51, they were added to the existing database and the developed DEA model was re-run. The efficiency scores for BO50 and BO51 were found to be 1.00 and 0.83 , respectively. Since BO50 is a part of the efficient frontier (i.e., efficiency score is equal to 1.00 ), the decision makers should make positive bidding decision for this opportunity. On the other hand, BO51 is not a part of the efficient frontier; thus, the decision makers should not bid for this opportunity. This finding is very reasonable because BO50 performs better than BO51 in most of the dimensions, except $\mathrm{NF}_{6}, \mathrm{PF}_{3}, \mathrm{PF}_{6}$, and $\mathrm{PF}_{8}$. Table 5 shows the actual values and targeted values of the variables for BO51.

If the actual values of the inputs and outputs were improved by the percentages presented in the last column of Table 5, BO51 would become a positive bidding opportunity. For instance, if the percentage of retention money was $1.66 \%$, contract price was $\$ 76,630,000$; project duration was 31.01 months;

Table 4. Numerical evaluations and actual values of the inputs and outputs for 2 new bidding opportunities.

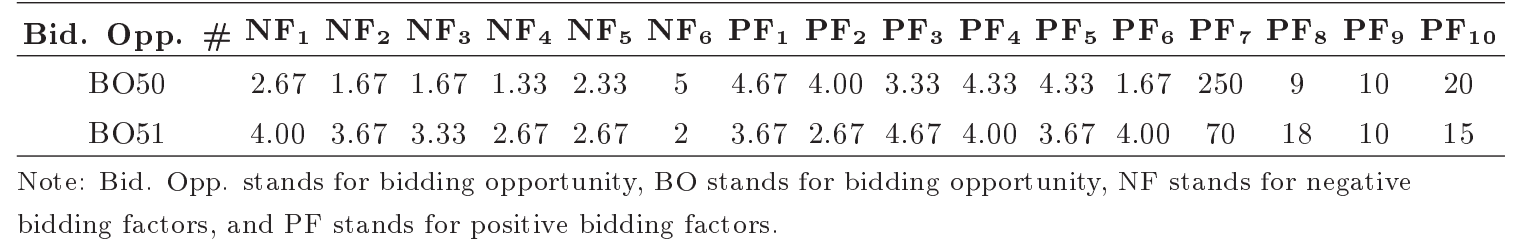


Table 5. Actual and projected values for the new bidding opportunity BO51.

\begin{tabular}{|c|c|c|c|c|}
\hline Variable & Variable definition & $\begin{array}{l}\text { Actual } \\
\text { value }\end{array}$ & $\begin{array}{l}\text { Projected } \\
\text { value }\end{array}$ & $\begin{array}{l}\text { Difference } \\
\qquad(\%)\end{array}$ \\
\hline $\mathrm{NF}_{1}$ & Complexity of bidding documents (i.e., drawings, specifications) & 4.00 & 2.64 & 34.12 \\
\hline $\mathrm{NF}_{2}$ & Unfamiliarity with the specific type of work & 3.67 & 2.81 & 23.34 \\
\hline $\mathrm{NF}_{3}$ & Cash flow requirements of the project & 3.33 & 2.76 & 17.04 \\
\hline $\mathrm{NF}_{4}$ & Technological difficulty of the project & 2.67 & 1.94 & 27.18 \\
\hline $\mathrm{NF}_{5}$ & Unsatisfactory terms of payment & 2.67 & 1.54 & 42.34 \\
\hline $\mathrm{NF}_{6}$ & Percentage of retention money & 2 & 1.66 & 17.04 \\
\hline $\mathrm{PF}_{1}$ & $\begin{array}{l}\text { Project's contribution to the strength of } \\
\text { company brand and reputation }\end{array}$ & 3.67 & 6.01 & 63.66 \\
\hline $\mathrm{PF}_{2}$ & $\begin{array}{l}\text { Project's contribution to the increase in the international } \\
\text { market share of the company }\end{array}$ & 2.67 & 4.64 & 73.96 \\
\hline $\mathrm{PF}_{3}$ & $\begin{array}{l}\text { Project's contribution to the development of } \\
\text { long-term relationships with other companies }\end{array}$ & 4.67 & 4.67 & 0.00 \\
\hline $\mathrm{PF}_{4}$ & Project's contribution to the improvement of the employees & 4.00 & 4.00 & 0.00 \\
\hline $\mathrm{PF}_{5}$ & Potential for gaining similar projects in the future & 3.67 & 5.18 & 41.12 \\
\hline $\mathrm{PF}_{6}$ & Potential for gaining long-term profit & 4.00 & 4.33 & 8.37 \\
\hline $\mathrm{PF}_{7}$ & Contract Price & 70 & 76.63 & 9.47 \\
\hline $\mathrm{PF}_{8}$ & Project Duration & 18 & 31.01 & 72.29 \\
\hline $\mathrm{PF}_{9}$ & Percentage of advance payment & 10 & 11.96 & 19.61 \\
\hline $\mathrm{PF}_{10}$ & Tender preparation time & 15 & 35.10 & 134.03 \\
\hline
\end{tabular}

percentage of advance payment was $11.96 \%$; tender preparation time was 35.10 days; the values of the remaining inputs (i.e., $\mathrm{NF}_{1}-\mathrm{NF}_{5}$ ) were decreased; and the values of the remaining outputs (i.e., $\mathrm{PF}_{1}-\mathrm{PF}_{6}$ ) were increased. Thus, the decision on BO51 would be "bid".

\subsection{Validating the developed DEA model}

In order to check the validity of the developed DEA model and its usability in their company, the opinions of three decision makers, who had the opportunity to utilize the proposed model, were sought through faceto-face interviews. The decision makers claimed that the developed DEA model was a useful and efficient tool and could be easily used in their company. They stated that the developed DEA model might provide their company with the following advantages:

- More objectivity;

- More systematic evaluation;

- Consideration of a combination of various quantitative and qualitative bidding factors (i.e., variables);

- Flexibility in identifying the variables;

- Easy implementation;

- Easy interpretation of the useful results provided by the developed model;

- Faster decision making process;

- Lower cost of the decision making process;
- Ability to make bid/no-bid decisions for new bidding opportunities.

\section{Conclusions}

To bid or not to bid for construction projects is a crucial strategic decision for survival, sustainability, and success of the contractors in the industry. Since bidding is a very costly and time consuming process, contractors have to develop winning proposals. Bid/no-bid decision is a complex and highly unstructured process as it is affected by numerous interrelated factors. It is commonly acknowledged that a systematic model, which simultaneously takes into account the impacts of all these interrelated factors and assists contractors in making sound bid/no-bid decisions, will be of great value.

This paper proposes a DEA-based decision making approach for making the bid/no-bid decision, which can be easily employed by any construction contracting company. The proposed approach mainly includes five stages, which are:

1. Forming the decision making team and identifying the key factors that may affect the bid/no-bid decision in the construction contracting company in question;

2. Determining the inputs and outputs of the DEA model for the bid/no-bid decision;

3. Collecting data; 
4. Performing DEA analysis on the collected data in order to measure the performance of the developed model;

5. Making the bid/no-bid decision for new bidding opportunities.

This approach was also applied in a large-scale Turkish construction constructing company, which predominantly undertakes international projects and is ranked among Top 225 International Contractors, in order to demonstrate how it can be used in a real situation. The interviews with three decision makers working in the contracting department revealed that 16 key factors affected the bid/no-bid decision in the studied company. These factors were then categorized as inputs (i.e., 6 inputs) and outputs (i.e., 10 outputs) depending on whether they needed to be minimized or maximized. Then, the actual values of these factors were determined for 49 previously evaluated bidding opportunities (i.e., DMUs) using the studied contracting company's database. The developed DEA model was run via OSDEA software and the accuracy rate of the developed model was found to be $92 \%$. Moreover, two new bidding opportunities faced by the studied company were evaluated using the developed DEA model and based on the DEA computations; the recommendation was to bid for one of these opportunities. The developed model also supplied the contractor with the projected values of the inputs and outputs for the negative bidding opportunity so that this bidding opportunity became positive. The opinions of three decision makers, who had the opportunity to utilize the proposed model, were sought through face-to-face interviews in order to check the validity of the developed DEA model and its usability in their company. The decision makers stated that the developed DEA model was a useful and efficient tool, and could be easily used in their company for evaluating bidding opportunities in future projects.

In the proposed approach, some of the bidding factors are qualitative and evaluated subjectively by decision makers on a predetermined scale. In most of the real-life problems, the information is uncertain and human's thoughts are imprecise; thus, it is almost impossible for decision makers to provide exact numerical values during the evaluation process. In these cases, decision makers may prefer to specify their preferences by linguistic variables, whose values are words or sentences in a natural or artificial language, and give interval judgments rather than fixed value judgments. Fuzzy set theory is a powerful tool for reflecting human reasoning and handling uncertainty and incomplete information when generating decisions [59]. In future studies, fuzzy numbers can be used when evaluating the qualitative factors. This is one of the future directions of this research.

\author{
Nomenclature \\ $\theta_{j} \quad$ Efficiency score of the $j$ th DMU \\ BO Bidding Opportunity \\ DEA Data Envelopment Analysis \\ DMU Decision Making Unit \\ $i \quad$ Number of input \\ j Number of DMU \\ $m \quad$ Total number of inputs \\ $n \quad$ Total number of DMUs \\ NF Negative bidding factors \\ $\mathrm{NF}_{1} \quad$ Complexity of bidding documents (i.e., \\ drawings, specifications) \\ $\mathrm{NF}_{2} \quad$ Unfamiliarity with the specific type of \\ work \\ $\mathrm{NF}_{3} \quad$ Cash flow requirements of the project \\ $\mathrm{NF}_{4} \quad$ Technological difficulty of the project \\ $\mathrm{NF}_{5} \quad$ Unsatisfactory terms of payment \\ $\mathrm{NF}_{6} \quad$ Percentage of retention money \\ $\mathrm{NF}_{i, j} \quad$ The $i$ th NF of the $j$ th DMU \\ $\mathrm{PF} \quad$ Positive bidding factors \\ $\mathrm{PF}_{1} \quad$ Project's contribution to the strength \\ of company brand and reputation \\ $\mathrm{PF}_{2} \quad$ Project's contribution to the increase \\ in the international market share of \\ the company \\ $\mathrm{PF}_{3} \quad$ Project's contribution to the \\ development of long-term relationships \\ with other companies \\ $\mathrm{PF}_{4} \quad$ Project's contribution to the \\ improvement of the employees \\ $\mathrm{PF}_{5} \quad$ Potential for gaining similar projects \\ in the future \\ $\mathrm{PF}_{6} \quad$ Potential for gaining long-term profit \\ $\mathrm{PF}_{7} \quad$ Contract price \\ $\mathrm{PF}_{8} \quad$ Project duration \\ $\mathrm{PF}_{9} \quad$ Percentage of advance payment \\ $\mathrm{PF}_{10} \quad$ Tender preparation time \\ $\mathrm{PF}_{r, j} \quad$ The $r$ th PF of the $j$ th DMU \\ $r \quad$ Number of output \\ $s \quad$ Total number of outputs \\ $u_{r} \quad$ Weight of the $r$ th output \\ $v_{i} \quad$ Weight of the $i$ th input \\ $x_{i, j} \quad$ The $i$ th input of the $j$ th DMU \\ $y_{r, j} \quad$ The $r$ th output of the $j$ th DMU
}

\section{Acknowledgement}

The authors would like to thank the Scientific Research Projects Coordination Unit (BAP) of Istanbul Techni- 
cal University for partial funding of this study with the project number 37672 .

\section{References}

1. Shafahi, A. and Haghani, A. "Modeling contractors' project selection and markup decisions influenced by eminence", International Journal of Project Management, 32(8), pp. 1481-1493 (2014).

2. Abbasianjahromi, H.R. and Rajaie, H. "Application of fuzzy CBR and MODM approaches in the project portfolio selection in construction companies", Iranian Journal of Science and Technology, Transactions of Civil Engineering, 37(C1), pp. 143-155 (2013).

3. Leśniak, A. and Plebankiewicz, E. "Modeling the decision-making process concerning participation in construction bidding", Journal of Management in Engineering, 31(2), 04014032, pp. 1-9 (2015).

4. Pekuri, A., Pekuri, H. and Haapasalo, H. "Business models and project selection in construction companies", Construction Innovation, 15(2), pp. 180-197 (2015).

5. Jarkas, A.M., Mubarek, S.A. and Kadri, C.Y. "Critical factors determining bid/no bid decisions of contractors in Qatar", Journal of Management in Engineering, 30(4), 05014007, pp. 1-11 (2014).

6. Ravanshadnia, M., Rajaie, H. and Abbasian, H. "A comprehensive bid/no-bid decision making framework for construction companies", Iranian Journal of Science and Technology, Transactions of Civil and Environmental Engineering, 35(C1), pp. 95-103 (2011).

7. Halpin, D., Construction Management, John Wiley and Sons, Inc. Hoboken, NJ (2006).

8. Kerzner, H. and Thamhain, H. "Project management operating guidelines: Directives", Procedures and Forms, Van Nostrand Reinhold, NY (1986).

9. El-Mashaleh, M. "Decision to bid or not to bid: A data envelopment analysis approach", Canadian Journal of Civil Engineering, 37(1), pp. 37-44 (2010).

10. Tan, Y., Shen, L. and Langston, C. "Contractors' competition strategies in bidding: Hong Kong study", Journal of Construction Engineering and Management, 136(10), pp. 1069-1077 (2010).

11. Gido, J. and Clements, J. Successful Project Management, South Western College Publishing, Ohio (1999).

12. Enshassi, A., Mohamed, S. and El Karriri, A. "Factors affecting the bid/no bid decision in the Palestinian construction industry", Journal of Financial Management of Property and Construction, 15(2), pp. 118-142 (2010).

13. Fayek, A., Ghoshal, I. and AbouRizk, S. "A survey of bidding practices of Canadian civil engineering construction contractors", Canadian Journal of Civil Engineering, 26(1), pp. 13-25 (1999).

14. Chua, D.K.S. and Li, D. "Key factors in bid reasoning model", Journal of Construction Engineering and Management, 126(5), pp. 349-357 (2000).
15. Lin, C. and Chen, Y. "Bid/no bid decision making a fuzzy linguistic approach", International Journal of Project Management, 22(7), pp. 585-593 (2004).

16. Egemen, M. and Mohamed, A. "A framework for contractors to reach strategically correct bid/no bid and mark-up size decisions", Building and Environment, 42(3), pp. 1373-1385 (2007).

17. El-Mashaleh, M. "Emprical framework for making to bid or not to bid decision", Journal of Management in Engineering, 29(3), pp. 200-205 (2013).

18. Ahmad, I. "Decision-support system for modeling the bid/no bid decision problem", Journal of Construction Engineering and Management, 116(4), pp. 595-607 (1990).

19. Chua, D., Li, D. and Chan, W. "Case-based reasoning approach in bid decision making", Journal of Construction Engineering and Management, 127(1), pp. 35-45 (2001).

20. Wanous, M., Boussabaine, A.H. and Lewis, J. "To bid or not to bid: A parametric solution", Construction Management and Economics, 18(4), pp. 457-466 (2000).

21. Tan, Y. and Shen, L. "A fuzzy competence requirement (FCR) model for competitive bidding strategy", Construction Innovation, 10(1), pp. 75-88 (2010).

22. Li, H. and Love, P.E.D. "Combining rule-based expert systems and artificial neural networks for mark-up estimation", Construction Management and Economics, 17(2), pp. 169-176 (1999).

23. Ahmad, I. and Minkarah, I. "Questionnaire survey on bidding on construction", Journal Management in Engineering, 4(3), pp. 229-243 (1988).

24. Cheng, M., Hsiang, C., Tsai, H. and Do, H. "Bidding decision making for construction company using a multi-criteria prospect model", Journal of Civil Engineering and Management, 17(3), pp. 424-436 (2011).

25. Chen, Y., Zhang, S.J., Liu, L.S. and Hu, J. "Risk perception and propensity in bid/no-bid decision-making of construction projects", Engineering, Construction and Architectural Management, 22(1), pp. 2-20 (2015).

26. Shash, A. "Factors considered in tendering decisions by top UK contractors", Construction Management and Economics, 11(2), pp. 111-118 (1993).

27. Lowe, D.J. and Parvar, J. "A logistic regression approach to modelling the contractor's decision to bid", Construction Management and Economics, 22(6), pp. 643-653 (2004).

28. Bageis, A.S. and Fortune, C. "Factors affecting the bid/no bid decision in the Saudi Arabian construction contractors", Construction Management and Economics, 27(1), pp. 53-71 (2009).

29. Enshassi, A., Mohamed, S. and El Karriri, A. "Factors affecting bid/no bid decision in the Gaza stripcontractors' perspectives", Revista ingeniería de construcción, 26(1), pp. 41-60 (2011). 
30. Hwang, J. and Kim, Y. "A bid decision-making model in the initial bidding phase for overseas construction projects", KSCE Journal of Civil Engineering, 20(4), pp. 1189-1200 (2016).

31. Cagno, E., Caron, F. and Perego, A. "Multi-criteria assessment of the probability of winning in the competitive bidding process", International Journal of Project Management, 19(6), pp. 313-324 (2001).

32. Wanous, M., Boussabaine, H.A. and Lewis, J. "A neural network bid/no bid model: the case for contractors in Syria", Construction Management and Economics, 21(7), pp. 737-744 (2003).

33. Egemen, M. and Mohamed, A. "SCBMD: A knowledge-based system software for strategically correct bid/no bid and mark-up size decisions", Automation in Construction, 17(7), pp. 864-872 (2008).

34. Oo, B., Drew, D. and Runeson, G. "Competitor analysis in construction bidding", Construction Management and Economics, 28(12), pp. 1321-1329 (2010).

35. Polat, G., Bingol, B.N. and Uysalol, E. "Modeling $\mathrm{bid} / \mathrm{no}$ bid decision using adaptive neuro fuzzy inference system (ANFIS): A case study", Construction Research Congress, Atlanta, GA, pp. 1083-1092 (2014).

36. Charnes, A., Cooper, W. and Rhoes, E. "Measuring the efficiency of decision making units", European Journal of Operational Research, 2(6), pp. 429-444 (1978).

37. Charnes, A., Cooper, W. and Rhodes, E. "Short communication: Measuring the efficiency of decision making units", European Journal of Operational Research, 3(4), pp. 429-444 (1979).

38. Charnes, A., Cooper, W. and Rhodes, E. "Evaluating program and managerial efficiency: An application of data envelopment analysis to program follow through", Management Science, 27(6), pp. 668-697 (1981).

39. Pilateris, P. and McCabe, B. "Contractor financial evaluation model (CFEM)", Canadian Journal of Civil Engineering, 30(3), pp. 487-499 (2003).

40. Cheng, E. and Li, U. "Exploring quantitative methods for project location selection", Building and Environment, 39(12), pp. 1467-1476 (2004).

41. McCabe, B., Tran, V. and Ramani, J. "Construction prequalification using data envelopment analysis", Canadian Journal of Civil Engineering, 32(1), pp. 183193 (2005).

42. El-Mashaleh, M., O'Brien, W. and Edward Minchin, R., Jr. "Firm performance and information technology utilization in the construction industry", Journal of Construction Engineering and Management, 132(5), pp. 499-507 (2006).

43. Vitner, G., Rozenes, S. and Spragget, S. "Using data envelop analysis to compare project efficiency in a multi-project environment", International Journal of Project Management, 24(4), pp. 323-329 (2006).

44. Cheng, E., Chaing, Y. and Tang, B. "Alternative approach to credit scoring by DEA: Evaluating borrowers with respect to PFI projects", Building and Environment, 42(4), pp. 1752-1760 (2007).
45. El-Mashaleh, M., Edward Minchin, R., Jr. and O'Brien, W. "Management of construction firm performance using benchmarking", Journal of Management in Engineering, 23(1), pp. 10-17 (2007).

46. Castro-Lacouture, D., Medaglia, A.L. and Skibniewski, M. "Supply chain optimization tool for purchasing decisions in B2B construction marketplaces", Automation in Construction, 16(5), pp. 569-575 (2007).

47. Gariaga, I., El-Diraby, T. and Osman, H. "Integrating value analysis and quality function deployment for evaluating design alternatives", Journal of Construction Engineering and Management, 133(10), pp. 761770 (2007).

48. Xue, X., Shen, Q., Wang, Y. and Lu, J. "Measuring the productivity of the construction industry in China using DEA-based malmquist productivity indices", Journal of Construction Engineering and Management, 134(1), pp. 64-71 (2008).

49. El-Mashaleh, M., Rababeh, S. and Hyari, K. "Utilizing data envelopment analysis to benchmark safety performance of construction contractors", International Journal of Project Management, 28(1), pp. 61-67 (2010).

50. Horta, I., Camanho, A. and Da Costa, J. "Performance assessment of construction companies integrating key performance indicators and data envelopment analysis", Journal of Construction Engineering and Management, $\mathbf{1 3 6}(5)$, pp. 581-594 (2010).

51. Lin, C. and Huang, H. "Improved baseline productivity analysis technique", Journal of Construction Engineering and Management, 136(3), pp. 367-376 (2010).

52. Horta, I., Camanho, A. and Lima, A. "Design of performance assessment system for selection of contractors in construction industry e-marketplaces", Journal of Construction Engineering and Management, 139(8), pp. 910-917 (2013).

53. Abbasian-Hosseini, S., Hsiang, S., Leming, M. and Liu, M. "From social network to data envelopment analysis: Identifying benchmarks at the site management level", Journal of Construction Engineering and Management, 140(8), p. 04014028 (2014).

54. El-Mashaleh, M.S. and Horta, I.M. "Evaluating contractors for bonding: DEA decision making model for surety underwriters", Journal of Management in Engineering, 32(1), pp. 1-7 (2016).

55. Sherman, H.D. and Zhu, J., Service Productivity Management Improving Service Performance Using Data Envelopment Analysis (DEA), Springer (2006).

56. Charnes, A., Cooper, W.W., Lewin, A.Y. and Seiford, L.M., Data Envelopment Analysis: Theory, Methodology, and Applications, Springer Science \& Business Media (2013).

57. Golany, B. and Roll, Y. "An application procedure for DEA", Omega, 17(3), pp. 237-250 (1989).

58. Banker, R.D., Charnes, A. and Cooper, W.W. "Models for the estimation of technical and scale inefficiencies in data envelopment analysis", Management Science, 30, pp. 1078-1092 (1984). 
59. Wong, B.K. and Lai, V.S. "A survey of the application of fuzzy set theory in production and operations management 1998-2009", International Journal of Production Economics, 129(1), pp. 157-168 (2011).

\section{Biographies}

Gul Polat is an Associate Professor of Civil Engineering at Istanbul Technical University, where she also serves as the Director of the Construction Management Graduate Program. She conducted her PhD studies at Istanbul Technical University and Illinois Institute of Technology in Chicago. Her main areas of research interest include decision support techniques, bidding strategies, resource management, marketing management, risk management, precast concrete systems, and most aspects of construction management. She has been involved with several research projects funded by The Scientific and Technological Research Council of Turkey (TUBITAK), Istanbul Technical University
(ITU), Feyzi Akkaya Fund for Supporting Scientific Activities (FABED), and other construction industry agencies. Her research work over the years has resulted in 86 technical papers in refereed journals and proceedings.

She has served over the years on several organizing committees of national and international conferences. Dr. Polat is currently serving on the editorial board of an international journal and routinely reviews papers for several scholarly publications.

Befrin Neval Bingol is a Research Assistant in the Department of Civil Engineering at Istanbul Technical University. She is currently a PhD candidate in the Structural Engineering program. She has been involved with two research projects funded by The Scientific and Technological Research Council of Turkey (TUBITAK) and Istanbul Technical University (ITU). Her research work over the years has resulted in 19 technical papers in refereed journals and proceedings. 